\title{
Influence of the link between resources and behavioural factors on the entrepreneurial intentions of electrical installation and maintenance work students
}

\author{
Ifeanyi Benedict Ohanu* (1) and Taiwo Olabanji Shodipe
}

\author{
* Correspondence: ifeanyi.ohanu@ \\ unn.edu.ng \\ Department of Industrial Technical \\ Education, Faculty of Vocational and \\ Technical Education, University of \\ Nigeria, Nsukka, Nigeria
}

\begin{abstract}
With a theory of planned behaviour (TPB) framework, this study examined how the link between resources and behavioural factors influence the entrepreneurial intentions of electrical installation and maintenance work (EIMW) students. It showed how available resources, which are defined as those controlled by the technical institutions but are accessible by the students, influence their behaviour and consequently their entrepreneurial intention. Different approaches are used in the study to analyse the primary data collected from EIMW students and an empirical analysis was done using structural equation model. The study showed the robustness of TPB model in the face of available resource that attitude, subjective norms and perceived behavioural control are behavioural factors that can be positively influence by several exogenous factors to enhance EIMW students' entrepreneurial intentions. The results of the study enhance the institutional training of staff and instructors at all management to give career counselling services and be vast in the career opportunities available in the field of study. This skill will motivate EIMW students towards establishing their business venture.
\end{abstract}

Keywords: Behavioural factors, Entrepreneurial intentions, Institutional resources, EIMW

\section{Introduction}

Technical and vocational education and training (TVET) is a system of education in addition to general education inculcates norms, morals, attitude and practical skills which enhances individual growth and sustainability. It is a foundation on which entrepreneurial education in technical institutions are established in Nigeria. Pavlova (2007) sees TVET as a pathway to enhance productivity and reduce poverty in the society. Technical and vocational education and training courses offered by students in technical colleges include automobile repair and maintenance, electrical works, welding and fabrication, carpentry and joinery, plumbing, bricklaying and concreting or masonry.

(c) The Author(s). 2021 Open Access This article is licensed under a Creative Commons Attribution 4.0 International License, which permits use, sharing, adaptation, distribution and reproduction in any medium or format, as long as you give appropriate credit to the original author(s) and the source, provide a link to the Creative Commons licence, and indicate if changes were made. The images or other third party material in this article are included in the article's Creative Commons licence, unless indicated otherwise in a credit line to the material. If material is not included in the article's Creative Commons licence and your intended use is not permitted by statutory regulation or exceeds the permitted use, you will need to obtain permission directly from the copyright holder. To view a copy of this licence, visit http://creativecommons.org/licenses/by/4.0/. 
Electrical installation and maintenance work (EIMW) is a technical vocational education and training course that capacitate the learners with skills in rural electrification, domestic installation, electrical testing and instrumentation, machine maintenance, etc. (Shodipe \& Ohanu, 2020; National Board for Technical Education (NBTE), 2012). To explain further, Ohanu et al. (2020) described the subject as one which inculcates theory and practical skills in electrical machine installation and maintenance, fault detection and repair services on electrical machines and battery charging.

Available and adequate use of resources in technical institutions can in no doubt build EIMW students career intentions. Resources used for effective teaching and learning EIMW in technical colleges are categorized into human, reputation, capital, physical science and technology, organization and management, policy, information and social resources but insufficient provision of these resources to the institutions may lead to inadequately trained graduates who will compete globally in the workforce (Nwokomah, 2005).

The purpose of this study is to find out the influence of the link between resources and behavioural factors on the entrepreneurial intentions of electrical installation and maintenance work students in Lagos state technical colleges with a sharp focus on the theory of planned behaviour.

Previous studies on entrepreneurial intentions are carried out on unskilled subject/ core area in developed, developing and underdeveloped countries but this focus majorly on skilled subject area which allows the learners to use their three domains of learning (cognitive, affective and psychomotor domain). The core contribution of this study is that physical resources, policy, information and social resources are fascinators of behaviour factors towards entrepreneurial intentions, although previous studies have looked into other aspect of resources: financial, human resources, materials, tools and equipment, safety practice and guided maintenance operations (Antonio et al., 2017; Ohanu et al., 2020; Shodipe et al., 2020).

\section{Literature review}

\section{Theory of planned behaviour}

This research study is built on the theory of planned behaviour of Ajzen (2001). The theory postulated that intention is a precursor to performing certain behaviours. Ozaralli and Rivenburgh (2016) noted that intention is a direct antecedent of real behaviour, and the stronger the intention for behaviour, the bigger the success of behaviour prediction or actual behaviour. The entrepreneurial ideologies assert that entrepreneurial intention (EI) could be self-acknowledged conviction by individuals who desire to start a new business enterprise, and tenacious about achieving this goals (Ridha et al., 2017). This is the first step leap in venture creation (Kautonen et al., 2015). The theory of planned behaviour (TPB) model propounded that attitudes, subjective norms and perceived behaviour controls are determinants of behavioural intentions (Ajzen, 1991).

Attitude is a psychological tendency that is expressed by evaluating a particular entity with some degree of favour or disfavour (Eagly \& Chaiken, 1993). Attitude towards the behaviour is the degree to which the individual holds an overall positive or negative personal valuation about being an entrepreneur Ozaralli and Rivenburgh (2016). Ajzen 
(2005) claims that people develop attitudes based on the beliefs they hold about the consequences of performing the behaviour.

Subjective norms refer to the perceived social pressure to perform or not to perform the behaviour. It influences individuals' perceived behavioural control and the attitude towards becoming an entrepreneur (Liñán et al., 2013; Linán \& Chen, 2009) as well as the intention to start a business (Schlaegel \& Koenig, 2014). The more individuals perceive that entrepreneurial behaviour is approved by those close to them, the stronger will be their entrepreneurial intention (Vanevenhoven \& Liguori, 2013).

Perceived behavioural control is an individual's assessments of the extent to which they are able to perform certain behaviour. The intention to start a business is driven by individuals' perceptions of their capability to act entrepreneurially (Amorós \& Bosma, 2014). This is an indication that individual's should have the belief that they have everything needed to establish and run the business successfully.

The link between intentions and behaviour through other relative factors had existed and have been found significant (Alam, Kousar \& Rehman, 2020; Antonio et al., 2017), while some are insignificant (Ana et al., 2016). Several recent studies support the validity of TPB for predicting entrepreneurial intentions and behaviour (Schlaegel \& Koenig, 2014); that is the reason for the application of the theory across all edifice, most especially entrepreneurship to predict individuals behaviour to venture into creating their own business. Also, this study tows the line with other previous studies to adopt the theory of planned behaviour to ascertain the entrepreneurial behaviour of EIMW students in technical colleges in Lagos state. Hence, the following was hypothesized:

H1. EIMW student's attitudes towards starting new businesses positively influence their entrepreneurial intentions.

H2. EIMW student's subjective norms towards starting a new business positively influence their entrepreneurial intentions.

H3. EIMW student's perceived behavioural control towards starting a new business positively influence their entrepreneurial intentions.

\section{Resource-based perspectives}

According to the resource-based perception, new venture creation involves collation and combination of heterogeneous resources which places the new venture at a competitive advantage and profit making (Kraaijenbrink et al., 2010). Entrepreneurial resources are the elements or a combination of elements to achieve the strategic objectives of new ventures towards service delivery (Barney, 1991). Access to resources is preliminary to new venture creation as explained in the entrepreneurial intentions model (Sandhu et al., 2011); these resources are either directly or indirectly available to students. Therefore, resources serve as a link between entrepreneurial behaviour and intentions (Ohanu et al., 2020). Unlike previous studies where familial resources, 
financial, human, tools and equipment, materials (Shodipe \& Ohanu, 2020), etc. are the core resources adopted. Access to resources vary from institution to institution and can rarely be transferred). Institutional resources are supports in colleges that emerge as the efficient way of obtaining necessary knowledge about entrepreneurship.

\section{Reputation resources}

Reputation is viewed as a perception of actions previously carried out and future individuals behaviour viewed with the context of what is ongoing in the market place (Adeosun \& Ganiyu, 2013) "Institutional reputation is a relatively stable issue which indicate a perceptual representation of an institution's past actions and future prospects compared against some standard" (Walker, 2010). This was characterized as an important source of competitive advantage (Basdeo et al., 2006; Ponzi et al., 2011). Reputation is described as a collective judgement of institutions based on the assessment of the performance of graduates from within the institutions over time (Barnett et al., 2006; Hormiga et al., 2011).

Creating awareness about institution reputations generate perceptions among investors, customers, competitors, employees and the general public about the foundation/source of the newly created business venture and their core values as a result of the new firm personnel competencies (Zerwas \& Von Korflesch, 2016). These perceptions motivate the public to accept the new business and their products (Fombrun \& Van Riel, 1997; Pakura \& Rudeloff, 2020). Reputation in previous studies played important roles in organizational build-up and served as a strategic way through which the organizations gained the public trust. Hence, this study intends to look at the influence of institutional reputations at fostering their graduates' behaviour to establish new business venture. Therefore, the following was hypothesized:

H4. EIMW student's access to reputation resources will positively influence their attitude, subjective norms and perceived behavioural control towards starting a new business.

\section{Physical resources}

According to the resource-based perspective, institutions portend that resources owned and controlled by these institutions have the capacity to stimulate certain individual to build a competitive ideology which leads to the establishment of their own business enterprise (King, 2007). Physical resource is one of the many tangible resources that stimulate entrepreneurial behaviour among intending entrepreneurs (Rose \& Kumar, 2007). Physical resources such as the plant, machinery, equipment, production technology and capacity contribute positively towards firm competitive advantage and eventually result in superior firm performance.

In this study, physical resources are the resources listed above and owned by the academic institutions. Therefore, this study tends to facilitate how access to these resources builds student's entrepreneurial intentions as a result of their motivated behaviour. Hence, the following was hypothesized: 
H5. EIMW student's access to physical resources will positively influence their attitude, subjective norms and perceived behavioural control towards starting a new business.

\section{Science and technology}

Entrepreneurship education in schools and colleges are geared towards the provision of skills and knowledge that are necessary to enhance entrepreneurial competencies in students. According to Fayolle and Gally (2008), entrepreneurship is seen as a skill and doings that is often linked with innovations, technology progress, economic growth, and employment creation. The application of science and technology in entrepreneurial education brought innovative skills and methods to creating and successful running of a new business venture (Akhmetshin et al., 2019).The government policy bridging school-industrial gap stimulates educational institutions and industries collaboration in the area of research project, provision of up-to-date tools and machineries, human resource training, etc. which are thoughtful to enhance student's innovative abilities (De Jong et al., 2015). Despite several efforts harnessed towards effective collaboration, Anderson, Daim and Lavoie (2007) insist that there is poor technology transfer as a result of several underlying factors. Technology transfer between school and industry will in no little way revive learner's entrepreneurial spirit to create their own business enterprise having been equipped with the technology know-how needed to successfully run the enterprise. Therefore, the following was hypothesized:

H6. EIMW student's access to science and technology resources will positively influence their attitude, subjective norms and perceived behavioural control towards starting a new business.

\section{Organization and management resources}

The introduction of entrepreneurship education into the country's education system is expected to bridge the gap between education, schooling and industrialization. Certain strategies were enacted to serve as a guideline to the implementation of the new education policy. These guidelines probably have an effect on schools, the management and development within the schools are likely to be even more effective (Minna et al., 2018). The school management team (principal, teachers and counsellors) has a major role to manage and guide the development of entrepreneurial education within the school (Minna et al., 2018). Entrepreneurial education encourages the growth of new business by utilizing their creative potentials and wealth of knowledge through higher education (Birdthistle et al., 2007). Galloway et al. (2005) added that educators are obligated to meet student's expectation thereby equipping them with the norms, morals and values needed for the economic growth and development. To stimulate students entrepreneurial behavioural, Gibbs (1993) opined that the school management team needs to act more as a guide and a partner through the learning process. Therefore, the following was hypothesized:

H7. EIMW student's access to organization and management resources will positively influence their attitude, subjective norms and perceived behavioural control towards starting a new business. 


\section{Information resources}

Information resources are business information relating to a business, procedures, techniques, methods, concepts, ideas, information relating to distribution, marketing, merchandising, selling, research, development, manufacturing, pricing and pricing strategies, etc. (Lawinsider dictionary, 2020; Moses, 2004). Information resources are the entrepreneurial information which deals with the analysis of a business to determine the skills and technical information needed for entrepreneurial sustenance (Ede, 2001). This information should be provided by either the institution's human resources or organization entrepreneurial experts through seminars, conferences or entrepreneurship education or training.

Previous studies of the roles of information had been carried out by comparison with knowledge (Vaghely \& Julien, 2010), information processing (Gaglio \& Katz, 2001), decision-making (Busentiz \& Barney, 1997), etc. This study seeks to find out how information resources could influence students behavioural factors to establish new business. Hence, the following was hypothesized:

H8. EIMW student's access to information resources will positively influence their attitude, subjective norms and perceived behavioural control towards starting a new business.

\section{Methodology}

This research study was executed in six technical colleges in Lagos state, south west Nigeria. Entrepreneurial education is the core value of these institutions with a major focus to add to general education, practical skill training, morals and attitude. Therefore, the institution produced students with entrepreneurial background which make students from these institutions a major area of focus.

\section{Sample}

Data were collected from a sample of 250 EIMW students using a structured questionnaire with the use of an adapted instrument. Using a multistage sampling technique, samples were selected from three schools randomly selected from the six technical colleges.

\section{Instrument for data collection}

The questionnaire has two parts; the first part measure the demographic contents while the other part measures the antecedents of intentions according to the theory of planned behaviour and is based on 7-point Likert rating scale, with a range from 7 (strongly agree) to 1 (strongly disagree). The adapted instruments are reputation (Caruana, 2000), physical resources (Barney, 1997), science and technology (Balan \& Lindsay, 2010), organization and management (Andriukaitiene, 2014), information resources (Hussain \& Kumar, 2007), attitude (Linán \& Chen, 2009), subjective norms (Krueger et al., 2000), perceived behavioural control (Linán \& Chen, 2009), and entrepreneurial intentions (Linán \& Chen, 2009). 


\section{Measurement validity}

The instrument for the study was subjected to content validity to find out the genuineness of the items on the questionnaire. Three experts from the Faculty of Vocational Technical Education, University of Nigeria, Nsukka, validated the instrument. The experts corrected some grammatical errors in the statement of the construct. Also, the instrument was subjected to both convergent and discriminant validity to check the degree of closeness and wideness of the variables.

Data collected were analysed using Statistical Package for Social Sciences (SPSS) version 23 to determine the mean of the various responses of the respondents and exploratory factor analysis, while SPSS AMOS v.25 was used to analyse the confirmatory factor analysis.

The reliability of the instrument was obtained with a measurement model using confirmatory factor analysis (CFA) to ascertain the goodness of fit model of the measurement scale. There was a good fit from the measurement which is an indication that the model and the data used are adequate. Hence, there is a good fit and a robust measurement model. Satorra-Bentler $\chi^{2}(250)=345.23(p=0.000)$ (Byrne, 2001), the BentlerBonett Normed Fit Index is robust $(\mathrm{NFI})=0.89$ (Lomax \& Schumacker, 2012), the Tucker-Lewis Index is robust (TLI) $=0.90$ (Prudon, 2015), the Comparative Fit Index is robust $(\mathrm{CFI})=0.91$ (Hair et al., 2010 ), the Bollen's fit index is robust (IFI) $=0.88$ (Kline, 2005), Goodness of Fit Index (GFI) = 0.91 (Schermelleh-Engel et al., 2003) and the Root Mean Square Error of Approximation is robust (RMSEA) $=0.021$ (Schermelleh-Engel et al., 2003). A critical view of the goodness of fit analysis showed that the model is suitable for measuring the constructs.

\section{Result and discussion}

\section{Confirmatory factor analysis}

To eliminate the multicolinearity problems, the principal component analysis (PCA) through confirmatory factor analysis was done showing the descriptive analysis and correlation matrix with the inter-relationship between various constructs as shown in Table 1.The KMO statistic for the study is 0.75, a value greater than 0.50 and the Bartlett's test is statistically significant at the $p<0.001$ level (Barba-Sanchez \& AtienzaSahuquillo, 2018). To ascertain discriminant validity, the convergent validity (average variance explained and composite reliability) was analysed in Table 2.

Table 1 showed the Pearson correlation matrix of the constructs. The result shows that there is a positive relationship between all the constructs except the relationship between science and technology and organization and management, subjective norms and science and technology and entrepreneurial intentions and science and technology. Also, result showed a range of low and moderate positive relationship between the constructs.

Table 2 shows the convergent validity [composite reliability (CR) and average variance extracted (AVE)] and discriminant validity of entrepreneurial intention factors which are a mathematical expression of the factor loadings of each constructs.

The two main indicators used to evaluate convergent validity are the composite reliability (C.R.) and average variance extracted (AVE) (Lee et al., 2007). The composite reliability of latent variables is formed by the reliabilities of all the measured variables 
Table 1 Means, standard deviation and correlation

\begin{tabular}{|c|c|c|c|c|c|c|c|c|c|c|c|}
\hline Variables & $x$ & SD & 1 & 2 & 3 & 4 & 5 & 6 & 7 & 8 & 9 \\
\hline$\overline{\text { AT }}$ & 4.87 & 1.27 & 1 & & & & & & & & \\
\hline SN & 5.10 & 1.52 & $0.351^{* *}$ & 1 & & & & & & & \\
\hline PBC & 5.21 & 0.97 & $0.213^{* *}$ & $0.281^{* *}$ & 1 & & & & & & \\
\hline REP & 5.16 & 1.32 & $0.421^{* *}$ & $0.170^{* *}$ & $0.348^{* *}$ & 1 & & & & & \\
\hline $\mathrm{PHY}$ & 5.19 & 1.41 & $0.134^{* *}$ & 0.163 & $0.187^{* *}$ & $0.219^{* *}$ & 1 & & & & \\
\hline SCT & 4.48 & 1.19 & $0.121^{*}$ & -0.151 & 0.336 & $0.061^{* *}$ & $0.142^{* *}$ & 1 & & & \\
\hline $\mathrm{OM}$ & 5.31 & 1.12 & $0.324^{* *}$ & $0.246^{* *}$ & $0.342^{* *}$ & $0.435^{* *}$ & $0.378^{* *}$ & -0.034 & 1 & & \\
\hline INF & 5.52 & 1.03 & $0.342^{* *}$ & $0.145^{* *}$ & $0.356^{* *}$ & $0.382^{* *}$ & $0.272^{* *}$ & 0.142 & $0.256^{* *}$ & 1 & \\
\hline $\mathrm{El}$ & 5.38 & 0.89 & $0.327^{* *}$ & $0.231^{* *}$ & $0.463^{* *}$ & $0.359^{* *}$ & $0.281^{* *}$ & -0.075 & $0.432^{* *}$ & $0.512^{* *}$ & 1 \\
\hline
\end{tabular}

$A T$ attitude, $S N$ subjective norms, $P B C$ perceived behavioural control, REP reputation resources, $P H Y$ physical resources, $S C T$ science and technology, OM organization and management, INF information resources, $E$ l entrepreneurial intentions ${ }^{*} p<0.05 ;{ }^{* *} p<0.01 ; N=250$

which represent an internal consistency between measured variables in a latent variable. Chang et al. (2012) noted that the higher the composite reliability, the higher is the internal consistency of a latent variable. Fornell and Larcker (1981) is of the opinion that convergent validity is adequate when constructs present an average variance extracted greater than 0.5 and composite reliability greater than 0.7 .

Assessing the validity in this study, the correlations of the different constructs must be lower than the square root of their average variance extracted (Kerlinger \& Lee, 2000; Fornell \& Larcker, 1981). A critical view of Tables 1 and 2 showed the square root of the average variance extracted value for the variables is consistently greater than their correlations and this shows satisfactory discriminant validity among variables. Hence, it shows that the data collected is sufficient enough for the model measures.

\section{Hypothesis and path coefficient}

In view of the model path analysis, the standardized regression estimate of students' entrepreneurial intentions describes the level of degree of influence of resources and behavioural antecedents towards entrepreneurial intentions. The critical ratio is the commonly recommended basis for testing statistical significance of SEM components

Table 2 Validities

\begin{tabular}{|c|c|c|c|c|}
\hline \multirow[t]{2}{*}{ Constructs } & \multicolumn{2}{|c|}{ Convergent validity } & \multirow{2}{*}{$\begin{array}{l}\text { Discriminant } \\
\text { validity }\end{array}$} & \multirow{2}{*}{$\begin{array}{l}\text { Cronbach } \\
\text { alpha (a) }\end{array}$} \\
\hline & $\overline{\text { AVE }}$ & CR & & \\
\hline Attitude & 0.51 & 0.72 & 0.71 & 0.75 \\
\hline Subjective norms & 0.62 & 0.69 & 0.78 & 0.82 \\
\hline Perceived behavioural control & 0.48 & 0.82 & 0.69 & 0.69 \\
\hline Reputation resources & 0.53 & 0.75 & 0.73 & 0.81 \\
\hline Physical resources & 0.59 & 0.78 & 0.77 & 0.71 \\
\hline Science and Technology & 0.52 & 0.68 & 0.72 & 0.75 \\
\hline Organization and management & 0.45 & 0.73 & 0.67 & 0.76 \\
\hline Information resources & 0.47 & 0.85 & 0.69 & 0.79 \\
\hline Entrepreneurial intentions & 0.42 & 0.72 & 0.65 & 0.81 \\
\hline
\end{tabular}


with C.R. values beyond \pm 2.58 establishing significance at $p<0.01$ level (Byrne, 2001) (Fig. 1).

Table 3 path coefficient and hypothesis test for the entrepreneurial intention model. Electrical installation maintenance and work (EIMW) students' attitude regress significantly and positively with their entrepreneurial intention with $p<0.01$ and critical ratio above the cut-off mark. Therefore, hypothesis 1 is accepted. Also, electrical installation maintenance and work students' subjective norms does not regress significantly with entrepreneurial intention with $p>0.01$ and critical ratio less than the cut-off mark; therefore, hypothesis 2 is rejected. EIMW students perceived behavioural control regress significantly with entrepreneurial intentions with $p<0.01$ and critical ratio above the cut-off mark; hence, hypothesis 3 is accepted. Access to reputation resources regress significantly with EIMW students' attitude, subjective norms, and perceived behavioural control with $p<0.01$ and critical ratio above the cut-off mark; therefore, hypothesis 4 is accepted. Access to physical resources regress significantly and positive with EIMW students' attitude and perceived behavioural control with $p<0.01$ but not with subjective norms with $p>0.01$ and critical ratio below cut-off mark; hence, hypothesis 5 is partly accepted. Access to science and technology resources regress significantly and positively with EIMW students' attitude and subjective norms with $p<0.01$ and critical ratio above the cut-off but not with perceived behavioural control with $p>$ 0.01 and critical ratio less than the cut-off mark; therefore, hypothesis 6 is partly accepted. EIMW students' access to institutions organization and management resources regress significantly and positive with their subjective norms and perceived behavioural control with $p<0.01$ and critical ratio above the cut-off mark but not with their attitude with $p>0.01$ and critical ratio below the cut-off mark; therefore, hypothesis 7 is partly accepted. Access to information resources regress significantly and positively with EIMW student's attitude, subjective norms and perceived behavioural control with $p<0.01$ and critical ratio above the cut-off mark; therefore, hypothesis 8 is accepted.

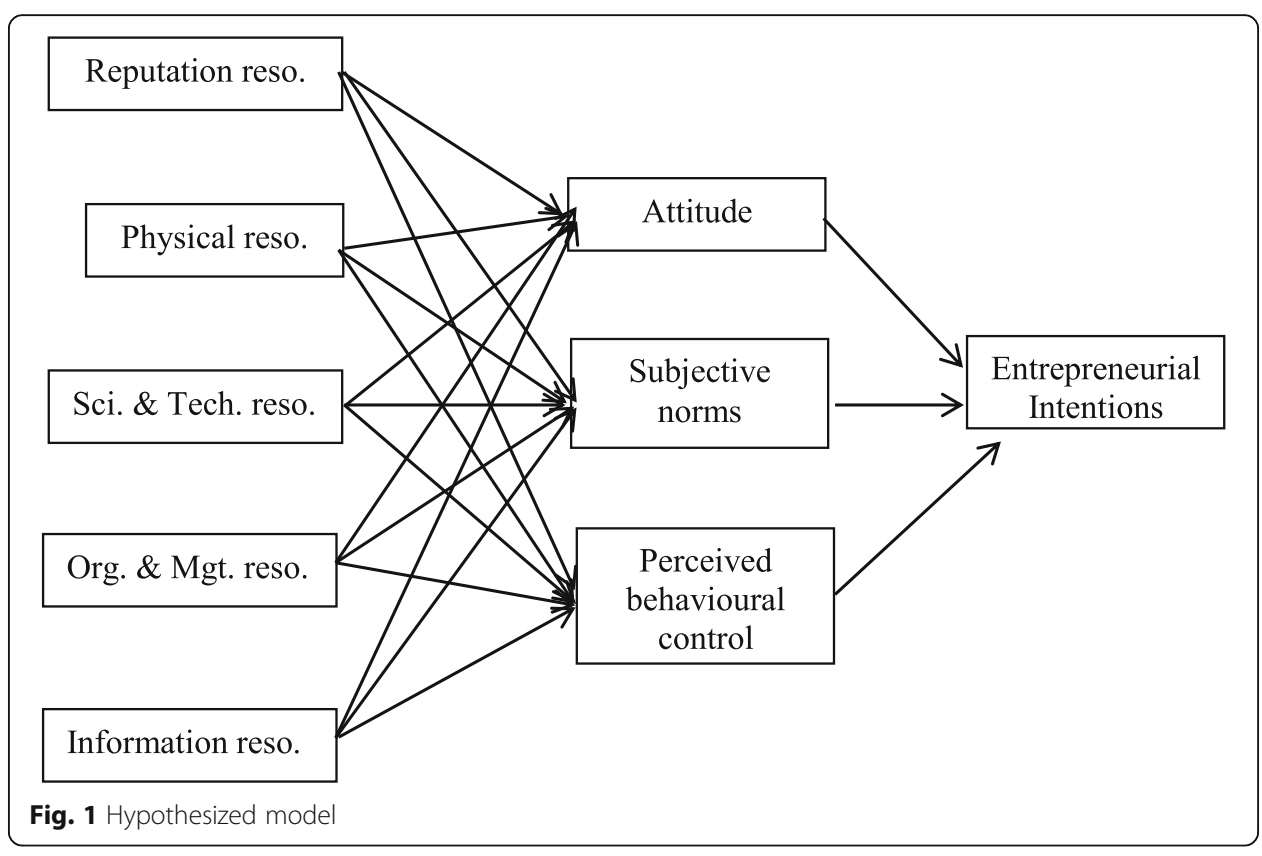


Table 3 Hypothesis test and path coefficients

\begin{tabular}{|c|c|c|c|c|c|c|c|c|}
\hline Hypo & Paths & & & Coefficient & S.E. & C.R. & $P$ & Decision \\
\hline 1 & AT & $<---$ & El & 0.229 & 0.065 & 4.45 & $* * *$ & Accepted \\
\hline 2 & SN & $<---$ & $\mathrm{El}$ & 0.032 & 0.031 & 0.341 & 0.675 & Rejected \\
\hline 3 & PBC & $<--$ & $\mathrm{El}$ & 0.351 & 0.045 & 5.326 & $* * *$ & Accepted \\
\hline \multirow[t]{3}{*}{4} & REP & $<--$ & AT & 0.035 & 0.064 & 3.591 & $* * *$ & Accepted \\
\hline & & & SN & 0.064 & 0.038 & 4.235 & $* * *$ & Accepted \\
\hline & & & PBC & 0.220 & 0.047 & 3.865 & $* * *$ & Accepted \\
\hline \multirow[t]{3}{*}{5} & PHY & $<---$ & AT & 0.032 & 0.056 & 3.945 & $* * *$ & Accepted \\
\hline & & & SN & -0.071 & 0.069 & -1.358 & 0.731 & Rejected \\
\hline & & & PBC & 0.053 & 0.051 & 6.237 & $* * *$ & Accepted \\
\hline \multirow[t]{3}{*}{6} & SCT & $<---$ & AT & 0.120 & 0.070 & 5.624 & $* * *$ & Accepted \\
\hline & & & SN & 0.031 & 0.631 & 3.726 & $* * *$ & Accepted \\
\hline & & & PBC & 0.082 & 0.057 & 2.102 & 0.664 & Rejected \\
\hline \multirow[t]{3}{*}{7} & $\mathrm{OM}$ & $<--$ & AT & -0.232 & 0.036 & -0.361 & 0.332 & Rejected \\
\hline & & & SN & 0.036 & 0.041 & 2.875 & $* * *$ & Accepted \\
\hline & & & PBC & 0.259 & 0.082 & 4.862 & $* * *$ & Accepted \\
\hline \multirow[t]{3}{*}{8} & INF & $<--$ & AT & 0.318 & 0.067 & 3.594 & $* * *$ & Accepted \\
\hline & & & SN & 0.421 & 0.046 & 5.962 & $* * *$ & Accepted \\
\hline & & & PBC & 0.031 & 0.051 & 6.537 & $* * *$ & Accepted \\
\hline
\end{tabular}

$A T$ attitude, $S N$ subjective norms, $P B C$ perceived behavioural control, REP reputation resources, $P H Y$ physical resources, SCT science and technology, OM organization and management, INF information resources, El entrepreneurial intentions ***Very Significant

\section{Discussion}

This paper sought to complement the different studies on TPB and the major roles played by its antecedents to ensure the establishment of new businesses by individuals and students. The approach used in the study passed through series of validation process to ensure that there is appropriate modification of the instrument on link between behavioural antecedents of available resources. The study found that available institutional resources have significant influence on students' behaviour towards entrepreneurial intentions. Based on the theoretical framework, all the questionnaire items are adapted from the empirical studies and it measures three behavioural antecedents (attitude, subjective norms and perceived behavioural control).

The result of the finding shows that institutional resources have both significant and non-significant influence on EIMW students' attitude towards entrepreneurship to establish a new business. Therefore, H1, H4, H5, H6 and H8 were accepted to have a significant influence. This result is consistent with the findings of Shapero (1982) whose contribution lays emphasis that students attitude towards entrepreneurship solely rely on exogenous factors such as resources (human resources, financial resources and tools and equipment) (Shodipe \& Ohanu, 2020). Also, Liñán (2008) emphasized that students attitude towards entrepreneurship is an incubator of their awareness of the importance and value of entrepreneurship. Also, Douglas and Shepherd (2002) found out that individuals with positive attitude bears risk, crave for independence and have strong intents to become entrepreneurs. Also, the finding is consistent with the findings of Mirjana et al. (2018) who found out the individuals entrepreneurial intentions are positively related to attitudes towards entrepreneurial behaviour. But $\mathrm{H} 7$ is rejected to have 
significant influence. This finding is in consonance with the study of Ridha et al. (2017) who found out an insignificant influence of attitude towards entrepreneurship.

This result of this study shows poor public perception (subjective norms) of entrepreneurship which led to the poor influence on students' entrepreneurial intentions as indicated in $\mathrm{H} 2$ and $\mathrm{H} 5$. Hence, subjective norm was rejected to have had a significant influence on students' entrepreneurial intentions and physical resources; this result is in line with the study of Krueger et al. (2000). But in some previous studies, subjective norms have significant influence on students' entrepreneurial intentions (Mirjana et al., 2018; Kautonen et al., 2015; Autio et al., 2001; Tounes, 2006) which gained support from the result of this study. Hence, this enables H4, H6, H7, and $\mathrm{H} 8$ to be accepted.

Perceived behavioural control is person's assessments of the extent to which he is able to perform certain entrepreneurial behaviour. The result of the study shows that perceived behavioural control (PBC) is significant with $\mathrm{H} 3, \mathrm{H} 4, \mathrm{H} 5, \mathrm{H} 7$, and $\mathrm{H} 8$. The result of the study is in consonance with the previous studies that found significant influence between $\mathrm{PBC}$, exogenous variables and entrepreneurial intentions (Dinc \& Budic, 2016; Ozaralli \& Rivenburgh, 2016; Doanh \& Bernat, 2019). In contrary, result showed that $\mathrm{PBC}$ is non-significant with the exogenous variable towards EI in H6. The finding of the study aligns with the previous study in which $\mathrm{PBC}$ shows a non-significant relationship among young agricultural entrepreneurs' (Arisandi, 2016; Ridha et al., 2017).

\section{Conclusion}

This study carried out a detailed analysis on the influence of the link between resources and behavioural factors on the entrepreneurial intentions of electrical installation and maintenance work students' entrepreneurial intentions in Lagos state, south west region in Nigeria, within the confines of theory of planned behaviour (Ajzen, 1991). The study showed how available resources stimulate EIMW students' behaviour to create their own business. Hence, the result of the study indicated that EIMW students' have positive attitude and perceived behavioural control towards the creation of their own business while subjective norms have an insignificant effect on their venture creation. Institutional reputations enhance their attitude, subjective norms and perceived behavioural control towards creating a new business. Also, available physical resources/infrastructures for students use stir their attitude and perceived behavioural control but not subjective norms towards entrepreneurial intentions. More also, available science and technology resources to the students influence their attitude, subjective norms but not perceived behavioural control towards innovative skills and method to create a new business. Organizational and management resources to EIMW students influence their subjective norms and perceived behavioural control but not their attitude towards creating a new business. Business information resources given to EIMW students influence their attitude, subjective norms and perceived behavioural control towards establishing a new firm.

New venture creation starts with intentions. The individual intention is influenced by certain level of planned behaviour (Krueger et al., 2000); likewise, this behaviour is influenced either positively or negatively by several exogenous factors (Shapero, 1982). Therefore, it is evident in this study that EIMW students' behaviour towards starting a new business is influenced by available resources within the school. 
The result of the study will extend the previous literatures on the robustness of theory of planned behaviour with utmost consideration on the influence school resources. This study shows that the antecedents of behavioural intentions are attitude, subjective norms and perceived behavioural control. With several literature evidences, the antecedents can be manipulated by exogenous factor to enhance EIMW students' entrepreneurial intention. In some other studies, the antecedents of behavioural intentions are used as a mediating variable between exogenous factors and a dependent variable (entrepreneurial intentions) (Entrialgo \& Iglesias, 2017). Also, the result is an indicator to the need for public private partnership in technical college to be able to provide the infrastructural needs of the institutions. There is also need for public orientation programme or services to educate the general public on the importance and needs of this system of education. The institutions personnel and instructors at all management level should be adequately trained to give career counselling service and be vast in the career opportunities available in the field of study.

The population of the students offering electrical installation and maintenance work in technical colleges are few compared to general education students; thus, the sample size for the study is affected. Also, higher number of the sample size are not fluent in reading and speaking English language, so the questionnaire items were read and interpreted to these set of students which gulp the buck of the time for the research. A further research can be carried out on behavioural antecedents between resources and entrepreneurial intentions among retiring civil servants in the south west zone of the country with concentration on their work experience, human resource relationship and the role of organization structure as factors that may influence their behaviour towards new venture creation.

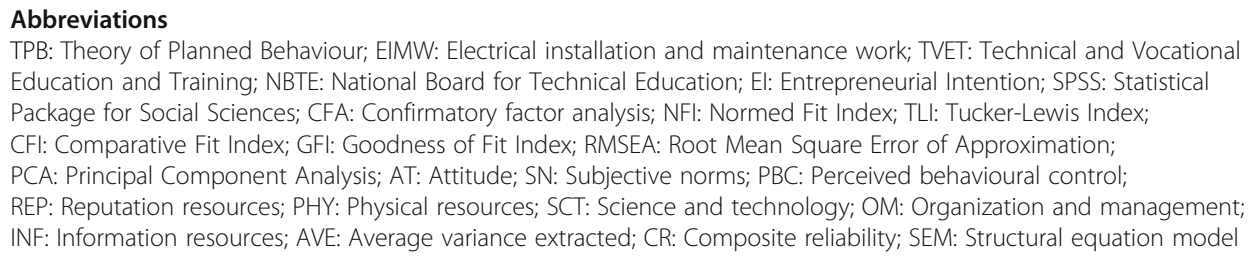

Acknowledgements

Not applicable.

Authors' contributions

IB-Conceived the topic, wrote the introduction and formulated the hypotheses. TO-Reviewed the literature and analysed data. IB and TO-Wrote the methodology, administered the instrument, discussed the finding and drafted. The author(s) read and approved the final manuscript.

Funding

The authors received no external funding for this research.

Availability of data and materials

The datasets generated and/or analysed during the current study are available from the corresponding author on reasonable request.

\section{Declarations}

Competing interests

The authors declare no competing interests. 
Received: 26 January 2020 Accepted: 1 March 2021

Published online: 16 April 2021

\section{References}

Adeosun, L. P. K., \& Ganiyu, R. A. (2013). Corporate reputation as a strategic asset. International Journal of Business and Social Science, 4(2), 220-225

Ajzen, I. (1991). The theory of planned behavior. Organizational Behavior and Human Decision Processes, 50(2), $179-211$. https://doi.org/10.1016/0749-5978(91)90020-T.

Ajzen, I. (2001). Nature and operation of attitudes. Annual Review of Psychology, 52(1), 27-58. https://doi.org/10.1146/annurev. psych.52.1.27.

Ajzen, I. (2005). Attitudes, personality and behaviour, (2nd ed., ). Open University Press (McGraw - Hill)

Akhmetshin, E. M., Mueller, J. E., Chikunov, S. O., Sechenov, I. M., Fedchenko, E. A., \& Pronskaya, O. N. (2019). Innovative technologies in entrepreneurship education: The case of European and Asian countries. Journal of Entrepreneurship Education, 22(1), 1-15

Alam, M. Z., Kousar, S., Shabbir, A., \& Kaleem, M. A. (2020). Personality traits and intrapreneurial behaviour: Moderated role of knowledge sharing behaviour in diverse group of employees in developing country. Asia Pacific Journal of Innovation and Entrepreneurship., 14(1), 31-46. https://doi.org/10.1108/APJIE-09-2019-0068.

Amorós, J. E. \& Bosma, N. (2014). Global Entrepreneurship Monitor 2013 Global Report. Fifteen Years of Assessing Entrepreneurship Across the Globe. https://www.researchgate.net/publication/264953640.

Ana, T. M., Makedonka, D., \& Jadranka, M. (2016). Drivers of entrepreneurial intentions among business students in Macedonia. Economic Research - Ekonomska Istrazivanja, 29(1), 1062-1074. https://doi.org/10.1080/1331677X.2016.1211 956.

Anderson, T. R., Daim, T. U., \& Lavoie, F. F. (2007). Measuring the efficiency of university technology transfer. Technovation, 27(5), 306-318, https://doi.org/10.1016/j.technovation.2006.10.003.

Andriukaitiene, R. (2014). A verification of a questionnaire to determine the level of management culture. Business and Management Research. https://doi.org/10.5430/bmr.v3n1p67.

Antonio, A., Samuel, B., \& Antonio-Jose, C. (2017). A missing link: The behaviour mediators between resources and entrepreneurial intentions. International Journal of Entrepreneurial Behavior and Research. https://doi.org/10.1108/IJEBR06-2016-0172.

Arisandi, D. (2016). Entrepreneurial intentions of post graduate students of Bogor Agricultural University, Agribusiness sector (case study of Sps - Ipb masters program students) (thesis). Bogor Agricultural University

Autio, E., Keeley, R. H., Klofsten, M., Parker, G. G. C., \& Hay, M. (2001). Entrepreneurial intent among students in Scandinavia and in the USA. Enterprise and Innovation Management Studies, 2(2), 145-160. https://doi.org/10.1080/14632440110094 632.

Balan, P., \& Lindsay, N. (2010). Innovation capability, entrepreneurial orientation and in Australian hotels: An empirical study. Cooperative Research Centre for Sustainable Tourism

Barba-Sanchez, V., \& Atienza-Sahuquillo, C. (2018). Entrepreneurial intention among engineering students: The role of entrepreneurship education. European Research on Management and Business Economics, 24(1), 53-61

Barnett, M. L., Jermier, J. M., \& Lafferty, B. A. (2006). Corporate reputation: The definitional landscape. Corporate Reputation Review, 9(1), 26-38. https://doi.org/10.1057/palgrave.crr.1550012.

Barney, J. B. (1991). Firm resources and sustained competitive advantage. Journal of Management, 17(1), 99-120. https://doi. org/10.1177/014920639101700108

Barney, J. B. (1997). Gaining and sustaining competitive advantage. AddisonWesley

Basdeo, D. K., Smith, K. G., Grimm, C. M., Rindova, V., \& Derfus, P. J. (2006). The impact of market action on firm reputation. Strategic Management Journal, 27(12), 1205-1219. https://doi.org/10.1002/smj.556.

Birdthistle, N., Hynes, B., \& Fleming, P. (2007). Enterprise education programmes in secondary schools in Ireland. Education + Training, 49(4), 265-276. https://doi.org/10.1108/00400910710754426.

Busentiz, L., \& Barney, J. (1997). Differences between entrepreneurs and managers in large organizations: Biases and heuristics in strategic decision - making. Journal of Business Venturing, 12(1), 9-30. https://doi.org/10.1016/S0883-9026(96)00003-1.

Byrne, B. M. (2001). Structural equation modeling with AMOS: Basics concepts, applications and programming. Lawrence Erlbaum Associates

Caruana, A. (2000). Measuring corporate reputation: A case example. Corporate Reputation Review, 3(1), 43-57. https://doi. org/10.1057/palgrave.crr.1540098.

Chang, C. C., Yan, C. F., \& Tseng (2012). Perceived convenience in an extended technology acceptance model: Mobile technology and English learning for college students. Australasian Journal of Educational Technology, 28(5), 809-826

De Jong, J. P., Parker, S. K., Wennekers, S., \& Wu, C. H. (2015). Entrepreneurial behavior in organizations: Does job design matter? Entrepreneurship Theory and Practice, 39(4), 981-995. https://doi.org/10.1111/etap.12084.

Dinc, M. S., \& Budic, S. (2016). The impact of personal attitude, subjective norms and perceived behavioural control on entrepreneurial intentions of women. Eurasian Journal of Business and Economics, 9(17), 23-25. https://doi.org/10.17015/ ejbe.2016.017.02.

Doanh, D. C., \& Bernat, T. (2019). Entrepreneurial self - efficacy and intention among Vietnamese students: A meta - analytic path analysis based on the theory of planned behaviour. Procedia Computer Science, 159, 2447-2460. https://doi.org/10.1 016/j.procs.2019.09.420.

Douglas, E. J., \& Shepherd, D. A. (2002). Self-employment as a career choice: Attitudes, entrepreneurial intentions, and utility maximization. Entrepreneurial Theory and Practice, 26(3), 81-90. https://doi.org/10.1177/104225870202600305.

Eagly, A. H., \& Chaiken, S. (1993). The psychology of attitudes. Harcourt Brace Jovanovich

Ede, E. O. (2001). Occupational analysis and course construction in industrial technical education. Godjiksons Publishers

Entrialgo, M., \& Iglesias, V. (2017). Are the intentions to entrepreneurship of men and women shaped differently? The impact of entrepreneurial role - model exposure and entrepreneurship education. Entrepreneurship Research Journal, 1-14. https://doi.org/10.1515/erj-2017-0013. 
Fayolle, A., \& Gally, B. (2008). From craft to science: Teaching models and learning processes in entrepreneurship education. Journal of European Industrial Training, 32(7), 569-593. https://doi.org/10.1108/03090590810899838.

Fombrun, C., \& Van Riel, C. (1997). The reputational landscape. Corporate Reputation Review, 1(1-2), 5-13. https://doi.org/10.1 057/palgrave.crr.1540008.

Fornell, C., \& Larcker, D. F. (1981). Evaluating structural equation models with unobservable variables and measurement error. Journal of Marketing Research, 18(1), 39-50

Gaglio, C. M., \& Katz, J. A. (2001). The psychological basis of opportunity identification: Entrepreneurial alertness. Small Business Economics, 16(2), 95-111. https://doi.org/10.1023/A:1011132102464.

Galloway, L., Anderson, M., Brown, W., \& Wilson, L. (2005). Enterprise skills for the economy. Education \& Training, 47(1), 7-17

Gibbs, P. A. (1993). Determinants of corporate restructuring: The relative importance of corporate governance, takeover threat and free cash flow. Strategic Management Journal, 14(1), 51-68. https://doi.org/10.1002/smj.4250140906.

Hair, J. F., Black, W. C., Babin, B. J., \& Anderson, R. E. (2010). Multivariate data analysis, a global perspective, (7th ed., ). Pearson Education

Hormiga, E., Batista-Canino, R. M., \& Sánchez-Medina, A. (2011). The impact of relational capital on the success of new business start-ups. Journal of Small Business Management, 49(4), 617-663. https://doi.org/10.1111/j.1540-627X.2011. 00339.x.

Hussain, A., \& Kumar, K. (2007). Utilization of information resources and services of the master school of management library: A study. International Journal of Library Science, 9(3), 39-52

Kautonen, T., Van Gelderen, M., \& Fink, M. (2015). Robustness of the theory of planned behavior in predicting entrepreneurial intentions and actions. Entrepreneurship: Theory and Practice, 39(3), 655-674. https://doi.org/10.1111/etap.12056.

Kerlinger, F. N., \& Lee, H. B. (2000). Foundations of behavioural research, (4th ed., ). Harcourt College Publishers

King, A. W. (2007). Disentangling interfirm and intrafirm causal ambiguity: A conceptual model of causal ambiguity and sustainable competitive advantage. Academy of Management Review, 32(1), 156-178. https://doi.org/10.5465/amr.2007.234 64002.

Kline, R. B. (2005). Principles and practice of structural equation modeling, (2nd ed., ). The Guilford Press

Kraaijenbrink, J., Spender, J.-C., \& Groen, A. J. (2010). The resource - based view: A review and assessment of its critiques. Journal of Management, 36(1), 349-372. https://doi.org/10.1177/0149206309350775.

Krueger, N. F., Reilly, M. D., \& Carsrud, A. L. (2000). Competing models of entrepreneurial intentions. Journal of Business Venturing, 15(5-6), 411-432. https://doi.org/10.1016/S0883-9026(98)00033-0.

Lawinsider dictionary (2020). https://www.lawinsider.com/dictionary/business-information

Lee, M. K. O., Cheung, C. M. K., \& Chen, Z. (2007). Understanding user acceptance of multimedia messaging services: An empirical study. Journal of the American Society forlnformation Science \& Technology, 58(13), 2066-2077. https://doi.org/1 0.1002/asi.v58:13.

Liñán, F. (2008). Skill and value perceptions: How do they affect entrepreneurial intention? International Entrepreneurship and Management Journal, 4(3), 257-272. https://doi.org/10.1007/s11365-008-0093-0.

Linán, F., \& Chen, Y. W. (2009). Development and cross-cultural application of a specific instrument to measure entrepreneurial intentions. Entrepreneurship Theory and Practice, 33(3), 593-617. https://doi.org/10.1111/j.1540-6520.2009.00318.x.

Liñán, F., Nabi, G., \& Krueger, N. (2013). British and Spanish entrepreneurial intentions: A comparative study. Revista De Economia Mundial, 33, 73-103

Lomax, R. G., \& Schumacker, R. E. (2012). A beginner's guide to structural equation modeling. Routledge Academic

Minna, H., Elena, R., \& Timo, P. (2018). Principals promoting entrepreneurship education: The relationships between development activities and school practices. Journal of Entrepreneurship Education, 21(1), 1-19

Mirjana, P. B., Ana, A., \& Marjana, M. S. (2018). Examining determinants of entrepreneurial intentions in Slovenia: Applying the theory of planned behaviour and an innovative cognitive style. Economic Research-Ekonomska Istraživanja, 31 (1), 14531471. https://doi.org/10.1080/1331677X.2018.1478321.

Moses, R. W. (2004). Straus's handbook of business information: A guide for librarians, students and researchers. Greenwood Publishing Group, Inc

National Board for Technical Education (2012). Curriculum for Technical colleges (Revised). NBTE press

Nwokomah, C. G. (2005). Strategy for attaining functional vocational and technical education in the 21st century in Nigeria. Journal of Education in Developing Areas, 1(14), 53-61

Ohanu, I. B., Shodipe, T. O., Chukwu, D. U., \& Chukwuma, J. N. (2020). Impact of behavioural factors as related to available resources on entrepreneurial intentions of electrical installation and maintenance works students. International Journal of Engineering Education, 36(1), 142-154

Ozaralli, N., \& Rivenburgh, N. K. (2016). Entrepreneurial intentions: Antecedents to entrepreneurial behaviour in the U.S.A and Turkey. Journal of Global Entrepreneurship Research, 6(3), 1-32

Pakura, S., \& Rudeloff, C. (2020). How entrepreneurs build brands and reputation with social media PR: empirical insights from start-ups in Germany. Journal of Small Business \& Entrepreneurship. https://doi.org/10.1080/08276331.2020.1728490.

Pavlova, M. (2007). Two pathways, one destination - TVET for a sustainable future. Unesco International Centre for Technical and Vocational Education and Training (UNESCO - UNVEVOC) in collaboration with Griffin Institute for Education Research, Australia

Ponzi, L., Fombrun, C., \& Gardberg, N. (2011). RepTrak ${ }^{\text {TM }}$ pulse: Conceptualizing and validating a short-form measure of corporate reputation. Corporate Reputation Review, 14(1), 15-35. https://doi.org/10.1057/crr.2011.5.

Prudon, P. (2015). Confirmatory factor analysis as a tool in research using questionnaire: A critique. Comprehensive Psychology, $4(10), 1-19$

Ridha, R. N., Burhanuddin, \& Wahyu, B. P. (2017). Entrepreneurship intention in agricultural sector of young generation in Indonesia. Asia Pacific Journal of Innovation and Entrepreneurship, 11(1), 76-89. https://doi.org/10.1108/APJIE-04-2017-022.

Rose, R. C., \& Kumar, N. (2007). Blockade for career advancement in Japanese organization abroad: The case of Malaysian subsidiaries. American Journal of Applied Sciences, 4(1), 8-13

Sandhu, M. S., Sidique, S. F., \& Riaz, S. (2011). Entrepreneurship barriers and entrepreneurial inclination among Malaysian postgraduate students. InternationalJournal of Entrepreneurial Behaviour \& Research, 17(4), 428-449. https://doi.org/10.11 08/13552551111139656. 
Schermelleh-Engel, K., Moosbrugger, H., \& Müller, H. (2003). Evaluating thefit of structural equation models: Test of significance and descriptive goodness-of-fit measures. Methods of Psychological Research Online, 8(2), 23-74

Schlaegel, C., \& Koenig, M. (2014). Determinants of entrepreneurial intent: A meta-analytic test andintegration of competing models. Entrepreneurship Theory and Practice, 38(2), 291-332. https://doi.org/10.1111/etap.12087.

Shapero, A. (1982). Social dimensions of entrepreneurship. In C. Kent, D. Sexton, \& K. Vesper (Eds.), The Encyclopedia of entrepreneurship, (pp. 72-90). Prentice-Hall

Shodipe, O. T., Nwahunanya, I., Martins, R. O., \& Abiodun, O. S. (2020). Available resources and laboratory/workshop practices as a correlate between electrical installation and maintenance work student's behaviour and intentions. International Journal of Innovative Science and Research Technology, 5(7), 706-711. https://doi.org/10.38124/JIRST20JUL400.

Shodipe, O. T., \& Ohanu, B. I. (2020). Antecedents of entrepreneurial intentions of electrical installation and maintenance work students' in technical colleges. Asia Pacific Journal of Innovation and Entrepreneurship. https://doi.org/10.1108/APJIE-08-2 019-0062.

Tounes, A. (2006). L'intention entrepreneuriale des etudiants. Le cas francais, Revue des sciences de gestion, 3(219), 57-65

Vaghely, I. P., \& Julien, P.-A. (2010). Are opportunities recognized or constructed? An information perspective on entrepreneurial opportunity identification. Journal of Business Venturing, 25(1), 73-86. https://doi.org/10.1016/j.jbusvent.2 008.06.004.

Vanevenhoven, J., \& Liguori, E. (2013). The impact of entrepreneurship education: Introducing the entrepreneurship education project. Journal of Small Business Management, 51(3), 315-328. https://doi.org/10.1111/jsbm.12026.

Walker, K. A. (2010). A systematic review of the corporate reputation literature: Definition, measurement, and theory. Corporate Reputation Review, 12(4), 357-387

Zerwas, C., \& Von Korflesch, H. (2016). A conceptual model of entrepreneurial reputation from a venture capitalists perspective. International Journal of Entrepreneurship and Innovation, 17(3), 143-154. https://doi.org/10.1177/146575031 6655900

\section{Publisher's Note}

Springer Nature remains neutral with regard to jurisdictional claims in published maps and institutional affiliations.

\section{Submit your manuscript to a SpringerOpen ${ }^{\circ}$ journal and benefit from:}

- Convenient online submission

- Rigorous peer review

- Open access: articles freely available online

- High visibility within the field

- Retaining the copyright to your article 